\title{
篗锿
}

\section{固体電池起電力法による合金および 酸化物の熱力学的研究}

\section{1.は じめに}

治金学的物質の高温飞括ける熱力学的性質は種々の方 法で測定され膨大なデータが蓄皕されてきている. 1957 年の Kiukkola と Wagner (1) とよる先駆的な論文扣よび 1962 年の Rapp と Maak ${ }^{(2)}$ とよる Cu-Ni 固体合金の活 量測定以来, 安定化ジルコニアをはじめとする固体電池 起電力法を用いて行なわれた研究は数多く, 得られた 成果には目を見張るものがある。その最も重要な原因は 固体電解質の高温注和ける安定性にあると思われるが, もちろ几固体電解質の特性が明確にされ，それをるとに 種々の利用方法が考案されたからに他ならない. 現在で は安定化ジルコニア等については原理的には出尽された 感があり， $\beta$-アルミナおよびその置換体や $\mathrm{CaF}_{2}$ 固体電 解質が多用されるようになってきている。

本稿は固体電池起電力法を用いた研究の集録を目的と

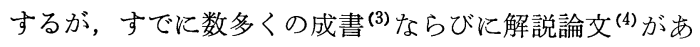
るので, 重複を避けるため主として 1980 年の Subbarao の集録(5)以降を扱うことにする。対象は固体拈よび液体 合金，酸化物，酸化物固溶体拉上び酸化物融体とする.

合金の熱力学的研究滛する闘大な論文の集録は Komarek ${ }^{(6)}$ が行なっている. 筆者ら (7) てのみ集録した。 また固体電解質の種々の利用方法につ いては後藤ら ${ }^{(4 \mathrm{f})(\mathrm{g}))}$ 扮よび筆者ら ${ }^{(8)}$ が解説している. 筆 者ら ${ }^{(8)}$ の解説と集録(7) と本稿とは一部を除いてできるだ け重複を避けるよう心がけたので併読されたい，安定化 ジルコニアを用いる場合の注意点は齋藤 ${ }^{(4(\mathrm{~h}))}$ が, $\mathrm{CaF}_{2}$ の場合は Kleykamp ${ }^{(4(i))}$ が述べている。その他 $\beta$-アル ミナ(9)についてはKummer, 二宮, Stevensらの, イ

* 大阪大学講師; 工学部冶金工学科

** 大阪大学教授; 工学部冶金工学科

Thermodynamic Study of Alloys and Oxides by Solid Electrolyte Cells ; Iwao Katayama, Zensaku Kozuka (Faculty of Eng, Osaka Univ., Suita)

Keywords : thermodynamic property, solid electrolyte, activity, free energy of formation, alloy, oxide, electromotive force, galvanic cell. slag 1985 年 11 月 27 日受理
片山箃* 幸塚善 作**

オン置換の特性などについては Yao ら, Farrington ら のレビューを参照されたい.

\section{2. 固体合金の熱力学的研究}

酸素イオン伝導体の固体電解質を用いて固体合金の活 量を測定したのは Rapp と $\mathrm{Maak}^{(2)}$ が初めてであり酸化 物を合金に混ぜて一定組成, 一定温度で酸素分圧 $\left(P_{\mathrm{O}_{2}}\right)$ が一定になることを利用した，安定化ジルコニア，トリ ア基, $\mathrm{CaF}_{2}$ などの固体電解質が用いられ多くの系につ いて測定されている(2)-(8).

表 1 に示すような系が実測されている。ここでは用い られた固体電解質によって分類した。

Notin ら (10) 法を用いて測定し，従来のペレットを用いた方法による 筆者らの結果 ${ }^{(11)}$ と非常によく一致した結果を得ている. Albert ら (19) は $\mathrm{Ta}, \mathrm{Ta}_{2} \mathrm{O}_{5}, \mathrm{Nb}, \mathrm{Nb}_{2} \mathrm{O}_{5}$ などを参照極に 用いて Nb-执よび Ta-合金中の酸素の活量を測定して いる. Schaller ら ${ }^{(25)}$ および Egan ${ }^{(27)}$ は測定極の蒸気 圧がかなり高くなるのでグラファイトルツボや Mo キャ ップで閉じ込めるセルを考案し， Co-Al 合金や $\mathrm{Na}-\mathrm{Sb}$ 合金の活量を測定している. Notin ら ${ }^{(26)}$ は Kleitz が 1968 年に考案した Pin Point Electrode Methodを用い

表 1 固体合金の熱力学的研究.

\begin{tabular}{|c|}
\hline $\begin{array}{l}\text { 安定化ジルコニア固体電解質 } \\
\quad \mathrm{Cu}-\mathrm{Ni}{ }^{(2)(10)(11)}, \mathrm{Cu}-\mathrm{Su}^{(12)}, \mathrm{CoGa}-\mathrm{X}(\mathrm{X}=\mathrm{Cu}, \mathrm{Ni}, \mathrm{Fe})^{(13)}\end{array}$ \\
\hline $\begin{array}{l}\mathrm{ThO}_{2} \text { 基固体電解質 } \\
\mathrm{Ni}-\mathrm{Mn}^{(14)}, \mathrm{Fe}-\mathrm{Mn}^{(15)}, \mathrm{Ni}-\mathrm{Zr}^{(16)}, \mathrm{Ni}-\mathrm{Ta}^{(17)}, \mathrm{Rh}-\mathrm{Nb}^{(18)}, \\
\mathrm{Nb}-\mathrm{V}-\mathrm{O}^{(19)}, \mathrm{Nb}-\mathrm{Mo}-\mathrm{O}^{(19)}, \mathrm{Ta}-\mathrm{W}-\mathrm{O}^{(19)}, \mathrm{Ta}-\mathrm{Re}-\mathrm{O}^{(19)}, \\
\mathrm{Ta}-\mathrm{N}-\mathrm{O}^{(19)}\end{array}$ \\
\hline $\begin{array}{l}\mathrm{CaF}_{2} \text { 固体電解質 } \\
\mathrm{Ni}-\mathrm{Mn}^{(14)}, \mathrm{Pd}-\mathrm{Gd}^{(20)}, \mathrm{Pd}-\mathrm{Y}^{(20)}, \mathrm{Pd}-\mathrm{Ce}^{(20)}, \mathrm{Ni}-\mathrm{La}^{(21)}, \\
\mathrm{Co}-\mathrm{La}^{(21)}, \mathrm{Y}-\mathrm{Fe}^{(22)}, \mathrm{Y}-\mathrm{Co}^{(23)}, \mathrm{Y}-\mathrm{Ni}^{(24)}, \mathrm{Co}-\mathrm{Al}^{(25)}, \mathrm{Ca}-\mathrm{Al}^{(26)}, \\
\mathrm{Ca}-\mathrm{Ag}^{(26)}, \mathrm{Ca}-\mathrm{Cu}^{(26)}, \mathrm{Ca}-\mathrm{Au}^{(26)(27)}, \mathrm{Na}-\mathrm{Sb}^{(27)}, \mathrm{Na}-\mathrm{Bi}^{(27)}\end{array}$ \\
\hline 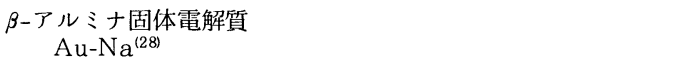 \\
\hline
\end{tabular}


て, $\mathrm{CaO}$ を飽和した $\mathrm{CaF}_{2}$ 固体電解質を利用して Ca合金中の Ca の活量を測定した。この方法によると電量 滴定により組成を連続的に変化できるので比較的短時間 で広い組成にわたっての測定ができるという利点がある が状態図が正確にわかっている必要がある。Egan ${ }^{(27)}$ は $\mathrm{Ca}-\mathrm{Sn}\left(X_{\mathrm{Ca}}=0.1\right)$ を参照極にして

$$
\begin{array}{l|l|l}
\mathrm{Ca}-\mathrm{Sn}(1) & \mathrm{CaF}_{2} & \mathrm{Ca}-\mathrm{Au}(\mathrm{s})\{\text { 又は } \mathrm{Na}-\mathrm{Bi}, \mathrm{NaF}\}
\end{array}
$$

なるセルを用いて Ca\{あるいは Na\}の活量を測定して いる. 少量の試料と多量の参照極が容器内に閉じ込めら れて $\mathrm{CaF}_{2}$ と接触し, 電量滴定によって試料の組成を変 化させている。従来の化合物は $\mathrm{CaAu}_{5}, \mathrm{CaAu}_{3}, \mathrm{CaAu}_{2}$ などとされているがこの方法により $\mathrm{CaAu}_{5}, \mathrm{Ca}_{2} \mathrm{Au}_{9}$, $\mathrm{Ca}_{2} \mathrm{Au}_{7}, \mathrm{CaAu}_{2}$ などが見い出されている. 伊藤ら ${ }^{(28)}$ は 硫黄センサ一用の $\beta$-アルミナ固体電解質に適する参照 極として $\mathrm{Au}+\mathrm{Au}_{2} \mathrm{Na}$ が優れていることを見い出した が, この 2 相共存域に打ける $a_{\mathrm{Na}}$ を $\beta$-アルミナを用い て決定している.

\section{3. 液体合金の熱力学的研究}

表 2 に示すような合金系について実測されている，実 験原理は固体合金の場合と同様であり，合金と共存する 酸化物の溶解度が小さくなければならない，溶解度が大 きければ補正する必要が生ずる(29)。 $\mathrm{Pb}-\mathrm{Sb}$ の場合は両 成分の酸化物の標準生成自由エネルギー $\left(\Delta G_{\mathrm{f}}^{\mathrm{o}}\right)$ が接近し ているために合金中に入れた酸化物が置換反応により $\mathrm{PbO}-\mathrm{Sb}_{2} \mathrm{O}_{3}$ 系になり, 合金の組成も変化し, メタル・ス ラグ両相で各成分が分配平衡する。杉本ら ${ }^{(31)}$ は合金中 の $P_{\mathrm{O}_{2}}$ を測定するとともにこれら両相について化学分 析を行ない, Mehrotra ら ${ }^{(51)} の \mathrm{~Pb}-\mathrm{Bi} \cdot \mathrm{PbO}-\mathrm{Bi}_{2} \mathrm{O}_{3}$ 系に 括ける解析方法を適用して活量を求めた. Larson Elliott(52) ${ }^{(5)} \mathrm{SO}_{2}$ または $\mathrm{S}_{2} 1$ 気圧 $(101325 \mathrm{~Pa})$ のとで $\mathrm{MO}+\mathrm{MS}$ ( $\mathrm{M}$ は金属)の示す $P_{\mathrm{O}_{2}}$ を測定し硫化物の $\Delta G_{\mathrm{f}}^{\circ}$

\section{表 2 液体合金の熱力学的研究.}

\begin{tabular}{|c|}
\hline $\begin{array}{l}\text { 安定化ジルコニア固体電解質 } \\
\mathrm{Ag}-\mathrm{Zn}^{(30)}, \mathrm{Ag}-\mathrm{Ga} \mathrm{a}^{(30)}, \mathrm{Ag}-\mathrm{In}^{(30)}, \mathrm{Pb}-\mathrm{In}^{(30)}, \mathrm{Pb}-\mathrm{Bi}^{(31)}, \\
\mathrm{Pb}-\mathrm{Ag}^{(31)}, \mathrm{Pb}-\mathrm{Sn}^{(31)}, \mathrm{Pb}-\mathrm{Sb}^{(31)}, \mathrm{Bi}-\mathrm{Sb}^{(32)}, \mathrm{Bi}^{\left(3 \mathrm{Sn}^{(33)},\right.} \\
\mathrm{Bi}-\mathrm{Ni}{ }^{(34)}, \mathrm{Cu}-\mathrm{Co}^{(35)}, \mathrm{Au}-\mathrm{Co}^{(36)}, \mathrm{Ga}-\mathrm{Sb}^{(37)}, \\
\mathrm{Ga}-\mathrm{Sb}-\mathrm{X}(\mathrm{X}=\mathrm{In}, \mathrm{Sn}, \mathrm{Ge}, \mathrm{Bi})^{(38)}, \mathrm{Ga}-\mathrm{Te}^{(38)}, \mathrm{Bi}-\mathrm{S}^{(39)}, \\
\mathrm{Ag}-\mathrm{S}^{(39)}, \mathrm{Pb}-\mathrm{S}-\mathrm{O}^{(39)}, \mathrm{Bi}-\mathrm{S}-\mathrm{O}^{(39)}, \mathrm{Ni}-\mathrm{Cr}^{(40)}, \mathrm{Fe}-\mathrm{Cr}^{(40)}\end{array}$ \\
\hline $\begin{array}{l}\mathrm{ThO}_{2} \text { 基固体電解質 } \\
\quad \mathrm{Ni}-\mathrm{Mn}^{(41)}, \mathrm{Co}-\mathrm{Mn}^{(41)}, \mathrm{Fe}-\mathrm{Mn}^{(41)}\end{array}$ \\
\hline $\begin{array}{l}\beta \text {-アルミナ固体電解質 } \\
\quad \mathrm{Na}-\mathrm{Ga}^{(42)}, \mathrm{Na}-\mathrm{Cd}^{(43)}, \mathrm{Na}-\mathrm{In}^{(43)}, \mathrm{Na}-\mathrm{Sn}^{(43)}, \mathrm{Na}-\mathrm{Tl}^{(44)} \text {, } \\
\quad \mathrm{Na}-\mathrm{Pb}^{(44)} \sim(46), \mathrm{Na}-\mathrm{Bi}^{(44)}, \mathrm{Na}-\mathrm{Al}^{(47)}, \mathrm{Cu}-\mathrm{Sn}^{(48)}\end{array}$ \\
\hline $\begin{array}{l}\mathrm{CaF}_{2} \text { 固体電解質 } \\
\quad \mathrm{Na}-\mathrm{Sb}^{277}, \mathrm{Na}-\mathrm{Bi}^{(27)}, \mathrm{K}-\mathrm{Bi}^{(27)}, \mathrm{Na}-\mathrm{Sn}^{(49)}\end{array}$ \\
\hline $\begin{array}{l}\mathrm{Na}^{+} \text {ガラス固体電解質 } \\
\mathrm{Na}-\mathrm{Tl}-\mathrm{Hg}^{(50)}\end{array}$ \\
\hline
\end{tabular}

を求めたが，武津ら ${ }^{(39)}$ はこの方法を金属 - 硫黄系融体 に発展させ，間接的に硫黄の活量を求めた． Ni-Cr液 体合金中の Crの活量は安定化ジルコニアを用いて Fruehan ${ }^{(40)}$ が測定している。筆者ら ${ }^{(53)}$ は $\mathrm{Cr}_{2} \mathrm{O}_{3}$ と共存 する $\mathrm{Ni}-\mathrm{Cr}$ 液体合金中の酸素の溶解度をサンプリング 法で調べあまり大きくないことを確かめ, $\mathrm{Cr}, \mathrm{Cr}_{2} \mathrm{O}_{3}$ 参 照極を含む $\mathrm{ZrO}_{2}+\mathrm{MgO}$ から成るセンサーを融体中に挿 入し, 短時間だけ起電力を測定するいわゆる消耗型セン サーの利用方法によって活量を測定した。この場合イオ ン輸率 $\left(t_{\text {ion }}\right)$ が 1 より小さしとが考兄られるので $P \ominus^{(54)}$ を用いて測定起電力に補正を行なって活量を算出 する必要がある，市販の各種ジルコニアの $P_{\ominus}$ は Iwase ら ${ }^{(55)}$ が実測している，液体合金では平衡に到達するの が速いため合金組成を変化させるのに電量滴定法が用い られることも多く, $\beta$-アルミナ, $\mathrm{CaF}_{2}, \mathrm{Na}^{+}$-ガラスなど を用いた場合，系を閉じて実験が行なわれる場合が多 W(27).

\section{4. 酸化物の熱力学的研究}

\section{(1) 2 元系酸化物}

固体，液体を問わず，多くの酸化物について測定され てきているが，測定方法に工夫がこらされ，温度範囲も 広くなっている。最近, 表 3 に示すよらな酸化物につい て実測されている．低い温度で空気・白金極を参照極に 用いると白金の酸化物を生じ起電力に影響を及ぼすこと が示されている(4(i)) が, Bannister ${ }^{(66)}$ は白金ペーストの 代りに $\mathrm{U}_{0.38} \mathrm{Sc}_{0.62} \mathrm{O}_{2 \pm x}$ が優れているとして $\mathrm{PbO} の \Delta G_{\mathrm{f}}^{\circ}$ の測定に用いている。 Khan ら ${ }^{(72)}$ は $\mathrm{ZrO}_{2}+\mathrm{Y}_{2} \mathrm{O}_{3}, \mathrm{ThO}_{2}$ $+\mathrm{Y}_{2} \mathrm{O}_{3}$ を用いて空気・白金極を参照極にして $\mathrm{ZnO} の$ $\Delta G_{\mathfrak{f}}^{\circ} \mathrm{Zn}$ の沸点を越えた温度まで測定しているが，従 来のデータと非常によい一致を示している筆者ら ${ }^{(73)}$ の 結果とは低い温度に执いても大きく異なっている，同様 な例が $\mathrm{Sb}_{2} \mathrm{O}_{3}$ にも見られ $\mathrm{Hahn} 5^{(69)}$ が従来と大きく異 なった值を出している。筆者ら ${ }^{(73)}$ は $\mathrm{Fe}, \mathrm{Fe}_{x} \mathrm{O}$ を参照極 にして $\mathrm{Sb}_{2} \mathrm{O}_{3}(1)$ について報告した ${ }^{(74)}$ がさらに空気・白 金極を用いて $\mathrm{Sb}_{2} \mathrm{O}_{3}(\mathrm{~s}, 1)$ について再測定を行なった ${ }^{(75)}$ が両者はよく一致している，起電力法では再現性の良い データが得られるが, 固体電解質の品質, リードの安定 性, セルの構造などについては常に注意を払う必要があ る.

表 3 酸化物の熱力学的研究.

$\mathrm{Bi}_{2} \mathrm{O}_{3}{ }^{(32)(56)}, \mathrm{CoO}^{(57) \sim(59)}, \mathrm{Cu}_{2} \mathrm{O}^{(57)(60) \sim(62)}, \mathrm{Fe}_{x} \mathrm{O}^{(60)}$, $\mathrm{Fe}_{3} \mathrm{O}_{4}{ }^{(60)}, \mathrm{IrO}_{2}{ }^{(62)}, \mathrm{MoO}_{2}{ }^{(63)(64)}, \mathrm{Mo}_{4} \mathrm{O}_{11}{ }^{(63)}$, $\mathrm{NiO}^{(57)(65)(91)}, \mathrm{PbO}^{(60)(66)}, \mathrm{PdO}^{(67)(68)}, \mathrm{Rh}_{2} \mathrm{O}_{3}{ }^{(62)}$, $\mathrm{Sb}_{2} \mathrm{O}_{3}{ }^{(32)(60)(69)(74)(75)}, \mathrm{SnO}_{2}{ }^{(56)(70)}, \mathrm{Tl}_{2} \mathrm{O}^{(71)}, \mathrm{ZnO}^{(72)(73)}$

\section{（2）複合酸化物}

複合酸化物のらち系統的に研究が進んでいるのはスピ

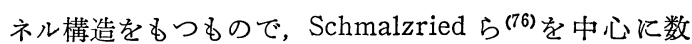


多く測定されていて，陽イオン分布などとの関連につい て論じられている。その他の複合酸化物についてもデー タが蓄積されてきている，各種の固体電解質を用いて表 4 に示すような系について測定されている。

表 4 複合酸化物の熱力学的研究.

\begin{tabular}{|c|c|}
\hline 系 & 複合酸化物(固体電解質) \\
\hline $\begin{array}{l}\mathrm{Ba}-\mathrm{Cr}-\mathrm{O} \\
\mathrm{Ba}-\mathrm{Fe}-\mathrm{O} \\
\mathrm{Ba}-\mathrm{Hf}-\mathrm{O}\end{array}$ & $\begin{array}{l}\mathrm{BaCrO}_{4}\left(\mathrm{BaF}_{2}\right)^{(77)} \\
2 \mathrm{BaO} \cdot \mathrm{Fe}_{2} \mathrm{O}_{3}, \mathrm{BaO} \cdot \mathrm{Fe}_{2} \mathrm{O}_{3}\left(\mathrm{BaF}_{2}\right)^{(78)} \\
\mathrm{BaHfO}_{3}\left(\mathrm{BaF}_{2}\right)^{(79)}\end{array}$ \\
\hline $\mathrm{Ca}-\mathrm{Al}-\mathrm{O}$ & $\begin{array}{l}\mathrm{CaO} \cdot 6 \mathrm{Al}_{2} \mathrm{O}_{3}, \mathrm{CaO} \cdot 2 \mathrm{Al}_{2} \mathrm{O}_{3}, \mathrm{CaO} \cdot \mathrm{Al}_{2} \mathrm{O}_{3} \\
3 \mathrm{CaO} \cdot \mathrm{Al}_{2} \mathrm{O}_{3}\left(\mathrm{Ca}-\beta^{\prime \prime} \text {-アルミナ)(80) }\right.\end{array}$ \\
\hline $\mathrm{Ca}-\mathrm{Ga}-\mathrm{O}$ & $\begin{array}{l}\mathrm{Ca}_{3} \mathrm{Ga}_{2} \mathrm{O}_{6}, \mathrm{Ca}_{3} \mathrm{Ga}_{4} \mathrm{O}_{9}, \mathrm{CaGa}_{2} \mathrm{O}_{4}, \mathrm{CaGa}_{4} \mathrm{O}_{7} \\
\left(\mathrm{CaF}_{2}\right)^{(81)}\end{array}$ \\
\hline $\mathrm{Ca}-\mathrm{Ge}-\mathrm{O}$ & $\mathrm{CaGeO}_{3}, \mathrm{CaGe}_{2} \mathrm{O}_{5}, \mathrm{CaGe}_{4} \mathrm{O}_{9}\left(\mathrm{CaF}_{2}\right)^{(82)}$ \\
\hline $\mathrm{Ca}-\mathrm{Hf}-\mathrm{O}$ & $\mathrm{CaHfO}_{3}\left(\mathrm{CaF}_{2}\right)^{(79)(83)}$ \\
\hline $\mathrm{Ca}-\mathrm{Zr}-\mathrm{O}$ & $\mathrm{CaZrO}_{3}\left(\mathrm{CaF}_{2}\right)^{(83)}$ \\
\hline $\begin{array}{l}\text { Co-Ga-O } \\
\text { Co-Ti-O }\end{array}$ & $\begin{array}{l}\mathrm{CoGa}_{2} \mathrm{O}_{4}(\mathrm{CSZ})^{(84)} \\
\mathrm{Co}_{2} \mathrm{TiO}_{4}, \mathrm{CoTiO}_{3-x}(\mathrm{CDT}, \mathrm{CSZ})^{(85)}\end{array}$ \\
\hline $\mathrm{Cr}-\mathrm{W}-\mathrm{O}$ & $\mathrm{CrWO}_{4}, \mathrm{Cr}_{2} \mathrm{WO}_{6}(\mathrm{YSZ})^{(86)}$ \\
\hline $\mathrm{Cu}-\mathrm{Ti}-\mathrm{O}$ & $\mathrm{Cu}_{3} \mathrm{TiO}_{4}(\mathrm{CSZ})^{(87)}$ \\
\hline $\begin{array}{l}\mathrm{Fe}-\mathrm{Al}-\mathrm{O} \\
\mathrm{Fe}-\mathrm{Mo}-\mathrm{O} \\
\mathrm{Fe}-\mathrm{Na}-\mathrm{O} \\
\mathrm{Fe}-\mathrm{W}-\mathrm{O}\end{array}$ & $\begin{array}{l}\mathrm{FeAl}_{2} \mathrm{O}_{4}(\mathrm{CSZ})^{(88)} \\
\mathrm{Fe}_{2} \mathrm{MoO}_{4}, \mathrm{Fe}_{2} \mathrm{Mo}_{3} \mathrm{O}_{8}\left(\mathrm{YDT}^{(89)}\right. \\
\mathrm{Na}_{2} \mathrm{FeO}_{2}, \mathrm{Na}_{2} \mathrm{Fe}_{2} \mathrm{O}_{4}\left(\mathrm{CaF}_{2}, \mathrm{CSZ}\right)^{(90)} \\
\mathrm{FeWO}_{4}(\mathrm{YDT})^{(91)}\end{array}$ \\
\hline $\begin{array}{l}\mathrm{Mg}-\mathrm{Ge}-\mathrm{O} \\
\mathrm{Mg}-\mathrm{Sb}-\mathrm{O} \\
\mathrm{Mn}-\mathrm{Al}-\mathrm{O}\end{array}$ & $\begin{array}{l}\mathrm{MgGeO}_{3}\left(\mathrm{CaF}_{2}\right)^{(82)} \\
\mathrm{MgSb}_{2} \mathrm{O}_{4}(\mathrm{CSZ})^{(75)} \\
\mathrm{MnAl}_{2+2 x} \mathrm{O}_{4+3 x}(\mathrm{YDT})^{(92)}\end{array}$ \\
\hline $\mathrm{Na}-\mathrm{Cr}-\mathrm{O}$ & $\mathrm{NaCrO}_{2}, \mathrm{Na}_{2} \mathrm{CrO}_{4}\left(\mathrm{YSZ}^{(93)}\right.$ \\
\hline $\begin{array}{l}\mathrm{Ni}-\mathrm{Al}-\mathrm{O} \\
\mathrm{Ni}-\mathrm{Cr}-\mathrm{O} \\
\mathrm{Ni}-\mathrm{Ga}-\mathrm{O} \\
\mathrm{Ni}-\mathrm{Mo}-\mathrm{O} \\
\mathrm{Ni}-\mathrm{Ti}-\mathrm{O} \\
\mathrm{Pb}-\mathrm{Zr}-\mathrm{O}\end{array}$ & $\begin{array}{l}\mathrm{NiAl}_{2} \mathrm{O}_{4}, \mathrm{NiAl}_{2.54} \mathrm{O}_{4.81}(\mathrm{CSZ}, \beta+\alpha \text { アルミナ) })^{(94)} \\
\mathrm{NiCr}_{2} \mathrm{O}_{4}(\mathrm{CSZ})^{(95)} \\
\mathrm{NiGa}_{2} \mathrm{O}_{4}(\mathrm{CSZ})^{(84)} \\
\mathrm{NiMoO}_{4}(\mathrm{CSZ})^{(64)} \\
\mathrm{NiTiO}_{3}\left(\mathrm{CSZ}^{(96)(97)}, \mathrm{YDT}\right)^{(96)} \\
\mathrm{Pb}_{1-x} \mathrm{ZrO}_{3-x}(\mathrm{CSZ})^{(98)}\end{array}$ \\
\hline RE-TR-O & $\begin{array}{l}\text { ( } \mathrm{RE}: \text { 希土類, } \mathrm{TR}: \text { 遷移金属) } \\
\mathrm{SmCoO}_{3}, \mathrm{EuCoO} 3 \mathrm{CuO}_{3}, \mathrm{GdCoO}_{3}, \mathrm{D}_{y} \mathrm{CoO}_{3}, \\
\mathrm{HoCoO}_{3}(\mathrm{YSZ})^{(99)} \\
\mathrm{LaCoO}_{3}(\mathrm{CSZ})^{(100)}, \mathrm{La}_{2} \mathrm{NiO}_{4}(\mathrm{YDT})^{(101)}, \\
\mathrm{LaMnO}_{3}(\mathrm{YSZ})^{(102)} \\
\mathrm{LaVO}_{3}-\mathrm{LaVO}_{4}\left(\mathrm{YSZ}^{(103)}\right. \\
\mathrm{LaFeO}_{3}, \mathrm{PrFeO}_{3}, \mathrm{EuFeO}_{3}, \mathrm{YFeO}_{3}(\mathrm{YSZ})^{(104)} \\
\mathrm{Y}_{3} \mathrm{Fe}_{5} \mathrm{O}_{12}, \mathrm{YFeO}_{3}(\mathrm{CSZ})^{(105)},\end{array}$ \\
\hline $\begin{array}{l}\text { Sr-Al-O } \\
\text { Sr-Hf-O } \\
\text { Sr-W-O }\end{array}$ & $\begin{array}{l}\mathrm{SrAl}_{2} \mathrm{O}_{4}(\mathrm{LDT})^{(106)} \\
\mathrm{SrHfO}_{3}\left(\mathrm{SrF}_{2}\right)^{(79)} \\
\mathrm{Sr}_{2} \mathrm{WO}_{5}, \mathrm{SrWO}_{4}, \mathrm{Sr}_{3} \mathrm{WO}_{6}\left(\mathrm{CDT}, \mathrm{CaF}_{2}\right)^{(106)}\end{array}$ \\
\hline $\mathrm{U}-\mathrm{Mo}-\mathrm{O}$ & $\mathrm{UMoO}_{5}(\mathrm{CSZ})^{(107)}$ \\
\hline $\begin{array}{l}\text { Zn-Ga-O } \\
\mathrm{Zn}-\mathrm{Sb}-\mathrm{O}\end{array}$ & $\begin{array}{l}\mathrm{ZnGa}_{2} \mathrm{O}_{4}(\mathrm{YSZ})^{(73)} \\
\mathrm{ZnSb}_{2} \mathrm{O}_{4}(\mathrm{YSZ})^{(75)}\end{array}$ \\
\hline$\beta$-アルミナ等 & 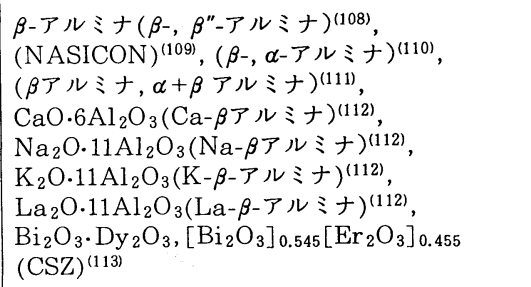 \\
\hline
\end{tabular}

* $\mathrm{CSZ}=\mathrm{ZrO}_{2}+\mathrm{CaO}, \mathrm{YSZ}=\mathrm{ZrO}_{2}+\mathrm{Y}_{2} \mathrm{O}_{3}, \mathrm{YDT}=\mathrm{ThO}_{2}+\mathrm{Y}_{2} \mathrm{O}_{3}$, $\mathrm{LDT}=\mathrm{ThO}_{2}+\mathrm{La}_{2} \mathrm{O}_{3}$
Levitskii ら ${ }^{(81)(83)}$ は $\mathrm{CaF}_{2}$ を用いた起電力法で, 測定 される電極に補助物質を添加し, たとえば (一) $\mathrm{O}_{2}, \mathrm{Pt} /$ $\mathrm{CaO}, \mathrm{CaF}_{2} / \mathrm{CaF}_{2} / \mathrm{CaHfO}_{3}, \mathrm{HfO}_{2}, \mathrm{CaF}_{2} / \mathrm{Pt}, \mathrm{O}_{2}(+)$ なる セルから $\mathrm{CaO}+\mathrm{HfO}_{2}=\mathrm{CaHfO}_{3}$ の反応の $\Delta G_{\mathrm{f}}^{\circ}$ を求めて いる. Elrefaie ら ${ }^{(94)}$ は CSZを用いて $\mathrm{NiAl}_{2} \mathrm{O}_{4}$ の $\Delta G_{\mathrm{f}}^{\circ}$ を測定し，さらにW, $\mathrm{WS}_{2}, \mathrm{Na}_{2} \mathrm{~S} / \alpha+\beta$ アルミナ/Ni， $\mathrm{NiO}$ と $\mathrm{W}, \mathrm{WS}_{2}, \mathrm{Na}_{2} \mathrm{~S} / \alpha+\beta$ アルミナ/Ni, $\mathrm{NiAl}_{2.54} \mathrm{O}_{4.81}$, $\mathrm{Al}_{2} \mathrm{O}_{3}$ との起電力から計算した值が前者のそれとよい一 致を示すことを確認した. Tretyakov ら (104) は $\mathrm{REFeO}_{3}$, $\mathrm{Fe}, \mathrm{RE}_{2} \mathrm{O}_{3} / \mathrm{YSZ} / \mathrm{Fe}_{2} \mathrm{O}_{3}, \mathrm{Fe}_{3} \mathrm{O}_{4} / \mathrm{YSZ} / \mathrm{air}, \mathrm{Pt}$ なるセルを 構成し(I)，(II)の間の $P_{\mathrm{O}_{2}}$ 差を小さくする目的で外側 のジルコニア底面に $\mathrm{Fe}_{2} \mathrm{O}_{3}, \mathrm{Fe}_{3} \mathrm{O}_{4}$ 混合物を入れて酸素 の透過による誤差を小さくして $\mathrm{REFeO}_{3}(\mathrm{RE}=\mathrm{La}, \mathrm{Pr}$, $\mathrm{Eu}) の \Delta G_{\mathrm{f}}^{\circ}$ 测定している.

$\beta$-アルミナ中の $a_{\mathrm{Na}_{2} \mathrm{O}}$ が $\beta$ アアルミナ, NASION など を用いて, $\mathrm{Au}+\mathrm{Au}_{2} \mathrm{Na}^{(108)}, \mathrm{Na}_{2} \mathrm{O}+\mathrm{NASICON}^{(109)}, \mathrm{W}+$ $\mathrm{WS}_{2}+\mathrm{Na}_{2} \mathrm{~S}^{(110)}$ (111), $\mathrm{NaF}+\mathrm{NiF}_{2}+\mathrm{Ni}^{(110)}$ などを参照極に して測定されている。活量值としてはほぼ一致している ような印象を与えるが，生のデータである起電力值に換 算すると個々の実験の䛊差をはるかに越えたバラッキが 存在するよらである。

\section{5. 酸化物固溶体の熱力学的研究}

合金の場合と同様に $\mathrm{M}, \mathrm{MO} / \mathrm{O}^{2-} /\left(\mathrm{MO}-\mathrm{M}^{\prime} \mathrm{O}\right), \mathrm{M}$ なる セルの起電力测定より $-Z E F=R T \ln a_{\mathrm{MO}}$ の関係か ら固溶体中の $\mathrm{MO}$ の活量が求められる $\left(\mathrm{M}, \mathrm{M}^{\prime}\right.$ は金属 を， $\mathrm{O}^{2-}$ は酸素イオン伝導体の固体電解質を表わす). ただし $/ \Delta G_{\mathrm{f}}^{\circ}(\mathrm{MO}) / \ll / \Delta G_{\mathrm{f}}^{\circ}\left(\mathrm{M}^{\prime} \mathrm{O}\right) /$ の関係が必要である. この手法を用いて酸化物の全率固溶体を示す系の活量が 測定されている。比較的最近の測定例を表 5 に示す.

表 5 酸化物固溶体の熱力学的研究.

$\mathrm{CoO}-\mathrm{MnO}^{(114)(115)}, \mathrm{NiO}-\mathrm{CoO}^{(116)}, \mathrm{NiO}-\mathrm{MgO}^{(117)(118)}$ $\mathrm{NiO}-\mathrm{MnO}^{(115)(119)}, \mathrm{MgO}-\mathrm{MnO}^{(120)}, \mathrm{Fe}_{3} \mathrm{O}_{4}-\mathrm{MFe}_{2} \mathrm{O}_{4}(\mathrm{M}=\mathrm{Zn}$, $\mathrm{Ni}, \mathrm{Cu}, \mathrm{Co}, \mathrm{Mg})^{(121)}, \mathrm{PbTiO}_{3}-\mathrm{PbZrO}_{3}{ }^{(122)}, \mathrm{Fe}_{1-x} \mathrm{Zn}_{x} \mathrm{O}_{y}{ }^{(123)}$, $\mathrm{Mg}_{y} \mathrm{U}_{1-y} \mathrm{O}_{2+x^{(124)}}\left(\mathrm{U}_{x} \mathrm{Zr}_{y} \mathrm{M}_{z}\right) \mathrm{O}_{l}(\mathrm{M}=\mathrm{La}, \mathrm{Nd}, \mathrm{Ce})^{(125)}$, $\mathrm{TiO}^{(126)}, \mathrm{VO}_{x}^{(127)}, \mathrm{Nb}_{2} \mathrm{O}_{5-x}{ }^{(128)}, \mathrm{MgO}-\mathrm{NiO}_{-} \mathrm{SiO}_{2}{ }^{(118)}$, $\mathrm{Li}_{2} \mathrm{O}-\mathrm{NiO}^{(129)}, \mathrm{Zr}_{1-y} \mathrm{Ca}_{y} \mathrm{O}_{2-y-x}(130)$

Torkar ら ${ }^{(116)}$ は $\Delta G_{\mathrm{f}}^{\circ}$ が非常に近い值をもつ $\mathrm{NiO}-\mathrm{CoO}$ 系の測定を行なっているが酸化物の置換反応を考慮に入 れた解析方法によって活量を算出している. 筆者ら (121) のスピネル固溶体の研究ではスピネル固溶体と酸化物 $\left(\mathrm{Fe}_{2} \mathrm{O}_{3}\right)$ を共存させて $P_{\mathrm{O}_{2}}$ を一定に保つ方法を採用して いる，酸化物あるいは複合酸化物のらちの不定化性を示 すものについて酸素の熱力学的数值 ${ }^{(124)}$-(127) YDT な゙を用いて測定されているが, 組成の調節に電 量滴定法が用いられている(124)(125). Schleifer ら ${ }^{(125)}$ $\mathrm{UO}_{2}-\mathrm{ZrO}_{2}-\mathrm{LnO}_{2-x}$ について実験終了後 $\mathrm{O} / \mathrm{M}$ 比を質量変 化と酸素分析とによって確認したところ,電量滴定によっ 
て算出された値とほとんど差がなかったと述べている。 表中の $\mathrm{MgO}-\mathrm{MnO}^{(117)}$ は $\mathrm{MgF}_{2}$ を, $\mathrm{PbTiO}_{3}-\mathrm{PbZrO}_{3}{ }^{(122)}$ は $\mathrm{PbF}_{2}$ を, $\mathrm{Li}_{2} \mathrm{O}-\mathrm{NiO}(129)$ は $\alpha-\mathrm{Li}_{2} \mathrm{SO}_{4}$ を固体電解質と して採用している。

\section{6. 酸化物融体, スラグ等の熱力学的研究}

酸化物融体中の $P_{\mathrm{O}_{2}}$ も安定化ジルコニア等を用いた センサーで測定できるが，安定化剈としては $\mathrm{MgO}$ の場 合が最も侵食されにくいことがわかっている。表 6 に示 されるような系が測定されている. 表中＊印はスラグと 溶融銀を平衡させ，銀中の $P_{\mathrm{O}_{2}}$ を測定してスラグの $P_{\mathrm{O}_{2}}$ とする方法を採用しているものである.

近年になって $\beta$-アルミナが酸化物融体中の活量測定 に用いられている。たとえば Neudorf ら ${ }^{(144)}$ は

$$
\left.\begin{aligned}
& \mathrm{O}_{2}(\mathrm{~g}),\left(\mathrm{Na}_{2} \mathrm{O}\right) \\
& \mathrm{Pt}, \mathrm{Na}_{2} \mathrm{O}-\mathrm{WO}_{3}(1)
\end{aligned}\right|_{\mathrm{I}} ^{/ \mathrm{Na}^{+}}{ }_{\text {II }}^{\mathrm{Pt},\left(\mathrm{Na}_{2} \mathrm{O}\right), \mathrm{O}_{2}(\mathrm{~g})}
$$

なるセルについての全反応 $1 / 2 \mathrm{O}_{2}(\mathrm{~g})_{\mathrm{I}}+\mathrm{Na}_{2} \mathrm{O}(\mathrm{I})$

表 6 酸化物融体等の熱力学的研究.

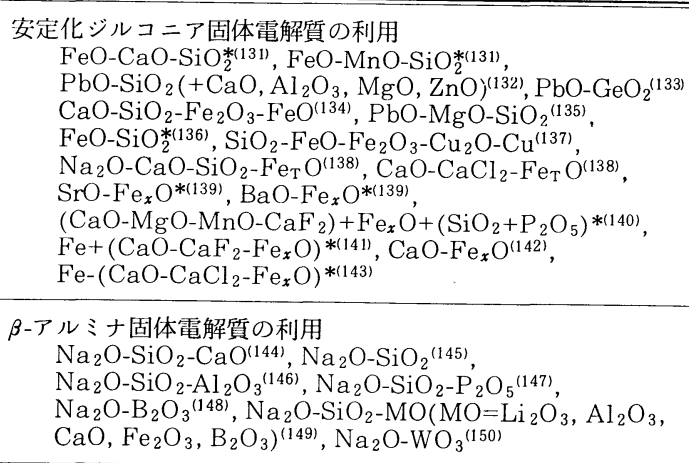

fused-silica の利用

$\mathrm{Na}_{2} \mathrm{O}-\mathrm{V}_{2} \mathrm{O}_{5}(151)$

$=1 / 2(\mathrm{~g})_{\pi}+\mathrm{Na}_{2} \mathrm{O}$ (II) に対して $\Delta G^{\circ}=-2 E F=R T$ ln $\left[a_{\mathrm{Na}_{2} \mathrm{O}(\mathrm{I})} / a_{\mathrm{Na}_{2} \mathrm{O}}(\mathrm{II})\right]$ を求めている. $\mathrm{Na}_{2} \mathrm{O}$ の標準状態は 1 気圧 $(101325 \mathrm{~Pa})$ に和ける純粋な $\mathrm{Na}_{2} \mathrm{O}(1)$ である。参照 極としては $\mathrm{W}+\mathrm{WS}_{2}+\mathrm{Na}_{2} \mathrm{~S}^{(150)}, \mathrm{Na}_{2} \mathrm{O}+\mathrm{SiO}_{2}+\mathrm{Fe}_{2} \mathrm{O}_{3}{ }^{(147)}$ などが用いられている。

Itoh $ら^{(148)}$ は $\mathrm{Pt}, \mathrm{O}_{2} / 0.05 \mathrm{Na}_{2} \mathrm{O} \cdot 0.95 \mathrm{~B}_{2} \mathrm{O}_{3} / \beta$-アルミナ/ $(1-x) \mathrm{Na}_{2} \mathrm{O} \cdot x \mathrm{~B}_{2} \mathrm{O}_{3} / \mathrm{O}_{2}$, Pt なるセルを図 1 のように構成 した.

$$
\begin{aligned}
-E & =(R T / 2 F) \ln \left(a_{\mathrm{O}^{2}-} / a_{\mathrm{O}_{2}-}^{\circ}\right)+\text { junction potential } \\
& =(R T / 2 F) \ln \left(a_{\mathrm{O}^{2-}} / a_{\mathrm{O}}^{\circ}-\right)+(R T / F) \ln \left(a_{\mathrm{Na}}+/ a_{\mathrm{Na}}^{\circ}\right) \\
& =(R T / 2 F) \ln \left(a_{\left.\mathrm{Na}_{2} \mathrm{O} / a_{\mathrm{Na}_{2}}^{\circ} \mathrm{O}\right)}^{\circ}\right.
\end{aligned}
$$

の関係より $\mathrm{Na}_{2} \mathrm{O}-\mathrm{B}_{2} \mathrm{O}_{3}$ 融体の熱力学的性質を求めてい る.このセル構造により $\beta$-アルミナが溶解してスラグ

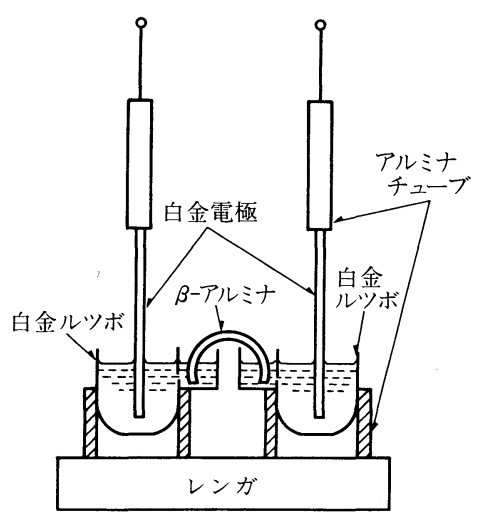

図 1 1. 七ル (Pt) $\mathrm{O}_{2}\left|0.05 \mathrm{Na}_{2} \mathrm{O} \cdot 0.95 \mathrm{~B}_{2} \mathrm{O}_{3}\right| \beta-ア ル ミ$ ナ| $(1-x) \mathrm{Na}_{2} \mathrm{O} \cdot x \mathrm{~B}_{2} \mathrm{O}_{3} \mid \mathrm{O}_{2}(\mathrm{Pt})$ の概略図 ${ }^{(148)}$.

を污染するとしてもその影響が小さくてすむ。また平衡 に到達する時間も短いとのことである。Mittal ら(151)は $\mathrm{V}_{2} \mathrm{O}_{5}-\mathrm{Na}_{2} \mathrm{O}(1)$ の $a_{\mathrm{Na}_{2} \mathrm{O}}$ を測定するのに fused silicaを 用いている。 $\beta$-アルミナを用いるとこの融体は這い上り 現象を起こすことと固体電解質を侵食するためである.

$$
\text { 7. おわりに }
$$

固体電池起電力法に限ったことではないが, 高温におい て測定対象がかわればそれぞれに応じて実験上の問題点 が生じる。それらを解決すべく固体電解質の利用方法が 工夫され, 電解質の品質の向上もあり広い領域で固体電 解質センサが使われるよらになってきた。主としてここ 5 年余りの論文について, 治金学的物質の熱力学的研究 に用いられた例を列挙したが，この他に液体金属および 合金中の酸素に関する研究 ${ }^{(29)}(152)$, 硫黄を含む系(153), 固体シリケート ${ }^{(154)}$ 等に関する論文も非常に多く，紙面 の都合で入れられなかった．溶銅中の微量元素に関する 熱力学的研究については本紙で大石と小野 ${ }^{(155)}$ が膨大な データを集録しているので参照されたい，筆者らの不注 意で集録漏れの論文もかなりあると思われるが扣許し願 いたい. 本稿が熱力学的性質に関心のある方々にとって 何らかの和役にたてば幸いである，文献コピーに協力い ただいた杦村彰治技官に感謝いたします。

\section{文献}

(1) K. Kiukkola and C. Wagner : J.Electrochem. Soc., 108 (1957) , 379.

(2) R.A.Rapp and F.Maak : Acta Met., 10 (1962), 63.

（3）たとえば, J.Hladik: Physics of Electrolytes, Vol. I, II, Academic Press, London, (1972); W.A.Fischer und D.Janke : Metallurgische Elektrochemie, Springer Verlag, Düsseldorf, (1975)など. 
（4）たとえば，(a) T.H.Etsell and S.N.Flengas : Chem. Rev.,j70(1970), 339 ; (b)松下涬,雄, 後藤和弘：日"本年金属学:会"会報, 5(1986)，133; (c) 幸塚善作, 森山徐一郎：日本金属学会会報, 10 (1971), 28；(d) 森山徐一郎：日本金属学会会 報, 16(1977) , 581; (e) 有田 稔, 後藤和弘：日 本金属学会会報, 18(1979), 755；(f) 永田和宏, 後藤和弘：鉄と鋼, $67(1981), 1899 ;(\mathrm{g})$ 後藤 和弘：日本金属学会会報, $23(1984), 978 ;(\mathrm{h})$ 齋藤安俊: 表面, 21 (1983), 629 ; (i) H. Kleykamp: Ber.Buns. Phys.Chem., 87 (1983), 777.

(5) E.C.Subbarao : Solid Electrolytes and Their Applications, Plenum Press, New York, (1980).

(6) K.L.Komarek: Z.Metallk., 64 (1973) , 325, 406 ; Ber. Buns Phys. Chem., 8(1977), 936.

（7）片山 嬖, 幸塚善作：日本金属学会会報, 21 (1982) , 242 .

（8）片山 蟋, 幸塚善作：日本金属学会会報，24 (1984), 630.

(9) J.T.Kummer : Prog. Solid State Chem., 7. Ed. by H.Reiss and J.O.McCaldin, Pergamon, Oxford, (1972) ; 二宮 清 : 電気化学, 48(1980), 354 ; R.Stevens and J.G.P.Binner : J.Mat. Sci., 19(1984), 695 ; Y.-F.Yu Yao and J.T. Kummer : J.Inorg. Nucl. Chem., 29(1967), 2453 ; G.C. Farrington and B. Dunn : Solid State Ionics, 7 (1982), 267 など.

(10) M. Notin, G. Lefebvre et J.Hertz : J. Solid State Chem., 28 (1979), 109.

（11）片山 嵈，島谷博之，幸塚善作：日本金属学会 誌, $37(1973), 509$.

(12) B.Predel : Calphad, 6 (1982), 199.

(13) 片山 樷, 吉村一哉, 幸塚善作 : 日本金属学会講 演概要，(1985·10月), 281 など

(14) M.Venkataraman and J.P.Hajra:Met. Trans., 14A (1983) , 2125.

(15) K.T.Jacob, J.P.Hajra and M.Iwase: Arch. Eisenhüttw., 55(1984), 421.

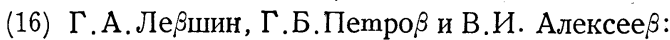
Док. Акад. Наук СССР, 269 (1983), 870.

(17) С.Н.Нестеренко и Л.Л.Мешко $\beta$ :Жур.Физ. Хим., 58(1984) , 979.

(18) H.Kleykamp : J.Less Common Met., 83 (1982), 105.

(19) E.Albert, E.Fromm and R.Kirchheim : Met. Trans., 14A (1983), 2117.

(20) S.Paasch and H.-J.Schaller: Ber. Buns.Phys. Chem., 87 (1983) , 812.

(21) Т.Н. Резухина и С.Б. Куце $\beta$ : Жур. Физ. Хим., 56 (1982) , 1, 278.

(22) P.R.Subramanian and J.F.Smith : Calphad, 8 (1984), 295.

(23) P.R.Subramanian and J.F.Smith:Met.Trans., 16A (1985) , 1195.

(24) P.R.Subramanian and J.F.Smith:Met.Trans., 16B (1985) , 577.

(25) H.-J.Schaller and T.Bretschneider:Z.Metallk., $76(1985), 143$.

(26) M.Notin and J.Hertz: Calphad, 6(1982), 49.

(27) J.J.Egan : High Temp. Sci., 19 (1985), 111.

(28) M.Itoh, E.Sugimoto and Z.Kozuka: Trans. JIM, 25 (1984), 504.

(29) たとえば, N.Kemori, I. Katayama and Z . Kozuka : J.Chem. Thermodyn., 14(1982) , 167.
(30) 亀田和夫, 吉田芳男, 坂入専司 : 岩手大学工学部 研究報告，32(1979)，161；36(1983)，91；日本金 属学会誌, 45 (1981), 614; Trans. JIM, 23 (1982)， 433.

（31）杉本栄佑，葉田茂樹，幸塚善作：日本鉱業会誌， 97 (1981), $1199 ; 98(1982), 429$.

（32）伊藤 聰, 阿座上竹四：日本金属学会誌，48 $(1984), 293$.

(33) R.Kammel, J.Osterwald und T.Oishi : Metall, 37 (1983), 141.

(34) M.Iwase and A.McLean : Met. Trans., 14B (1983) , 765.

(35) P.Taskinen : Z.Metallk., 73 (1982), 445.

(36) E.J.Grimsey and J.M.Toguri:Can.Met.Quart., 23 (1984), 303.

(37) T.J.Anderson and T.L.Aselage : J.Chem. Thermodyn., 15(1983), 927.

(38) たとえば, 片山嚴, 中山純一郎, 大杉 仁, 中井哲弥，幸塚善作：日本金属学会講演概要, $(1985 \cdot 10$ 月), 280 .

（39）武津典彦, 幸塚善作:日本金属学会誌，44(1980), 412 ; 45 (1981), 1263 ; Met. Rev. M.M.I.J., 1 (1984)，27；日本鉱業会誌，99(1983)，49.

(40) R.J.Fruehan: Trans. Met. Soc. AIME, 242 (1968) , 2007 ; 245 (1969), 1215.

(41) K. T. Jacob : Met. Trans., 13B(1982), 283 ; K.T.Jacob and M.Iwase:Z.Metallk, 73 (1982), 316 ; K.T.Jacob, J.P.Hajra and M.Iwase: Arch.Eisenhüttw., 55 (1984), 421.

(42) L. Zabdyr and K. Fitzner: Arch. Hutn., 23 (1983) , 221.

(43) M.Iwase, S.Sugino and E.Ichise : J.Chem. Thermodyn., 17 (1985), 601.

(44) M.Iwase, S.Sugino, E.Ichise and Y.Waseda : High Temp.Mater. Proc., 6(1984), 143.

(45) M.-L.Saboungi, S.J.Herron and R.Kumar: Ber. Buns. Phys. Chem., 89 (1985) , 375.

(46) D.J.Fray and B.Savory: J.Chem. Thermodyn., $7(1975), 485$.

(47) R.J.Brisley and D.J.Fray : Met. Trans., 14B (1983) , 435.

(48) J.A.Little and D.J.Fray: Trans. Inst. Min. Met., 88(1979) , C229.

(49) R.Alqasmi and J.J.Egan: Ber. Buns. Phys. Chem., 87 (1983) , 815.

(50) М.В.Деррачева, Н.Л.Паноßа, Г.Р.Ховдаберрено а и Л.Ю.Козин : Жур. Физ. Хим., 58 (1984), 305.

(51) G.M. Mehrotra, M.G.Frohberg and M.L. Kappor : Can. Met. Quart., 15(1976), 215 ; Z. Metallk., 67 (1976) , 186.

(52) H.R.Larson and J.F.Elliott : Trans.Met.Soc. AIME, 239 (1967), 1713.

（53）片山 撖，中西哲也，家守伸正，幸塚善作：日本 金属学会講演概要, (1983·10月) , 466 .

(54) H.Schmalzried:Z.Phys. Chem. N.F., 38(1963), 87.

(55) M.Iwase, E. Ichise, M. Takeuchi and T. Yamasaki : Trans. JIM, 25 (1984), 43.

(56) S.C.Schaefer : Bureau of Mines Rept. Invest., (1984), No.8906.

(57) N.Kemori, I.Katayama and Z.Kozuka : J. Chem. Thermodyn., 11 (1979), 215.

(58) B.Sossa, P.Ochin and G.P.Ervas:High Temp. High Press., 14 (1982), 593.

(59) P.Taskinen : Scand.J.Metall., 12(1983) , 255. 
（60）杉本栄佐，葉田茂樹，幸塚善作：日本金属学会 誌, 44 (1980) , 644.

(61) P.Taskinen: Scand. J.Metall., 10 (1981), 189.

(62) C.Mallika, O.M.Sreedharan and M.S.Chandrasekharaiah : J.Less. Common Met., 107 (1985) , 203.

(63) H.Kleykamp and A.Supawan:J.Less-Common Met., 63 (1979) , 237.

(64) L.Pejryd : High Temp. High Press., 16(1984), 403.

(65) H.Comert and J.N.Pratt:J.Chem.Thermodyn., $16(1984), 1145$.

(66) M.J.Bannister:J.Chem. Thermodyn., 16(1984), 787.

(67) В.А.Ле Кицкий, П.Б.Нарцук, М.Л.Ковба и Ю.Я.Сколис:Жуе. Физ. Хим., 56 (1982), 2405.

(68) C.Mallika, O.M.Sreedharan and J.B.Gnanamoorthy : J.Less. Common Met., 95(1983), 213.

(69) S. K. Hahn and D.A. Stevenson : J.Chem. Thermodyn., 11 (1979) , 627.

(70) R.Kammel, J.Osterwald und T.Oishi:Metall., $37(1983), 141$.

(71) S. Otsuka, T. Sano and Z. Kozuka : J.Chem Thermodyn., $12(1980), 1115$.

(72) G.M.Khan and M.S.Subhani : Z.Phys.Chem. Leipzig, 263 (1982), 1034.

(73) I. Katayama, A. Iseda, N. Kemori and Z. Kozuka : Trans. JIM, 23 (1982), 556.

(74) 片山 穤, 柴田 純, 幸塚善作 : 日本金属学会 誌, $39(1975), 990$.

(75) I.Katayama, S.Sugimura and Z.Kozuka: Trans. JIM 投稿予定.

(76) H.Schmalzried:Z.Phys. Chem.N.F., 25 (1960), 178 ; J.D. Tretyahos und H.Schmalzried : Ber. Buns. Phys. Chem., 69 (1965), 396 ; 70 (1966) , 180 など・

(77) B.Deo and V.B.Tare:Mat.Res.Bull., 11 (1976), 469.

(78) B.Deo, J.S.Kachhawaha and V.B.Tare:Met. Trans., 7B (1976) , 405.

(79) V.A.Levitskii, P.B.Narchuk, M.I.Kovba Jr. and Ya.I.Gerassimov: High Temp. Sci., 14 (1981) , 241.

(80) R.V.Kumar and D.A.R.Kay : Met. Trans., 16B (1985) , 107.

(81) Ya.Y.Scolis, V.A.Levitskii, L.N.Lykova and T. A. Kallinina : J. Solid State Chem., 38 (1981) , 10.

(82) Su-IL.Pyun : J.Amer. Ceram. Soc., 67 (1984), 594.

(83) В.А.Левичкий, П.Б.Нарцук и С.Л.Кашкорова : Жур. Физ. Хим., 56 (1982), 803.

(84) I. Katayama, N.Kemori and Z. Kozuka : J. Chem. Thermodyn., 11 (1979), 757.

(85) S.G.Popov and V.A.Levitskii : J.Solid State Chem, 38(1981), 1.

(86) K.T.Jacob : J.Mater. Sci., 15 (1980) , 2167.

(87) L.Pejryd and E.Rosén : High Temp. High Press., 14 (1982) , 599.

(88) F. A. Elrefaie and W. W. Smeltzer : Met. Trans., 14B (1983) , 85.

(89) H.Kleykamp and V.Schauer : J.Less-Common Met., 81 (1981) , 229.

(90) W.Dai, S.Seetharaman and L.-I.Staffansson: Met. Trans., 15B (1984), 319.

(91) H.Kleykamp : J.Less.Common Met., 71 (1980), 127.
(92) K.T.Jacob : Can. Met. Quart., 20 (1981), 89.

(93) O.M.Sreedharan, B.S.Madan and J.B.Gnanamoorthy : J.Nucl.Mater., 119(1983), 296.

(94) F.A.Elrefaie and W.W.Smeltzer : J.Electrochem. Soc., 128 (1981), 2237.

(95) H.Davies and W.W.Smeltzer : J.Electrochem. Soc., 121 (1974) , 543.

(96) G. Chattopadhyay and H. Kleykamp:Z.Metallk., 74 (1983), 182.

(97) L.Pejryd : Acta Chem. Scand., A38(1984), 241.

(98) K.T.Jacob and W.W.Shim : J.Amer.Ceram. Soc., 64 (1981) , 573.

(99) А.Н.Петров, А.Ю.Кроланев, В.М.Жуковский : Жур. Физ. Хим., 58(1984) , No.1, 50.

(100) O.M.Sreedharan and M.S.Chandrasekharaiah: Mat.Res. Bull., 7 (1972) , 1135.

(101) O.M.Sreedharan, M.S.Chandrasekharaiah and M.D.Karkhanavala : High Temp.Sci., 8 (1976), 179 .

(102) O.M.Sreedharan, R.Paukajavalli and J.B. Granamoorthy : High Temp. Sci., 16(1983), 251.

(103) R.Pankajavalli, O.M.Sreedharan and J.B. Granamoorthy : Trans. Ind. Inst. Metals, 36 (1983) , 250.

(104) Yu.D.Tretyakov, A.R.Kaul and V.K.Portnoy: High Temp. Sci., 9(1977), 61.

(105) W.Piekarezyk, W.Weppner and A.Rabenau: Mat. Res. Bull., 13(1978), 1077.

(106) V. A. Levitskii and Y. Y. Scolis : J. Chem. Thermodyn., 6(1974), 1181.

(107) G.Chattopadhyay, S.N.Tripathi and A.S. Kerkar : J.Amer.Ceram. Soc., 67 (1984) , 610.

(108) M. Itoh, K. Kimura and Z.Kozuka : Trans. JIM , 26 (1985) , 353.

(109) G.Róg, S.Koziński and A.K.Róg : Electrochim. Acta, 28 (1983), 43.

(110) F.A.Elrefaie and W.W.Smeltzer : J.Electrochem. Soc., 128(1981), 1443.

(111) A.Dubreuil, M.Malenfant and A.D.Pelton : J.Electrochem. Soc., 128(1981), 2006.

(112) R.V.Kumar and D.A.R.Kay : Met. Trans., 16B(1985) , 295.

(113) M.J.Verkerk and A. J. Burggraaf : J. Appl. Electrochem., 10 (1980), 677.

(114) H.Paulsson: Scand. J.Metall., 11 (1982), 276.

(115) C.R.A.Catlow, B.E.F.Fender and P.J.Hampson: J.Chem.Soc. Faraday Trans., 73 (1977), 911.

(116) K.Torkar und R.Schneider : J.Solid State Chem., 18(1976), 89.

(117) H.Paulsson : Chem. Scripta, 19(1982), 116.

(118) 白根義則：熊本大学工学部研究報告, 28(1979), 133.

(119) H.Paulsson and E.Rosén : Chem. Scripta, 11 (1977), 204.

(120) S.Raghavan, G.N.K.Iyengar and K.P.Abraham : J.Chem. Thermodyn., 17 (1985) , 585.

（121）片山，箃, 柴田 純, 青木松秀, 幸塚善作 : 日本 金属学会誌, 40(1976), 932 ; I. Katayama, Y. Watanabe and Z.Kozuka: Trans. JIM, 20 (1979) , 593 ; I. Katayama, T.Matsuda and Z. Kozuka:Technol. Rept. Osaka Univ., 30 (1980), 385 ; 片山 巌, 伊勢田敦朗, 幸塚善作 : 日本金 属学会誌, 47 (1983), 852 ; 日本金属学会講演概 要, $(1982 \cdot 10$ 月 ), 385 . 
(122) N.G.Smahl, G.Schwitzgebel,H.Kling and E. Speck : Mat. Res. Bull., 14 (1979) , 1213.

(123) Г.И.Сергеев, А.А. Лыкасов и В.В.Цьяцук: Tsvetn.Met., (1985) , No.1,20 ; Г.И.Сергеев, А. А. Лыкасов и Г. Г. Михайлов и И. Ф. Худяков: Акад. Наик СССР Электрохимиа, $21(1985), 455$.

(124) T.Fujino, J.Tateno and H.Tagawa: J.Solid State Chem., 24(1978), 11 ; J.Tateno,T.Fujino and H. Tagawa:J.Solid State Chem., 30(1979), 265.

(125) F.Schleifer, A.Naoumidis and H.Nickel : J. Nucl. Mater., 115(1983), 143

(126) R.Tetot, C.Picard and P.Gerdanian : J.Phys. Chem. Solids, 44 (1983) , 1059.

(127) И.А.Васильева и А.Н.Серегин : Жур. Физ. Хим., 56(1982), 1374.

(128) T.Matsui and K.Naito:J.Solid State Chem., 59 (1985), 228.

(129) S.Pizzini, R.Morlotti and V.Wagner : J.Electrochem. Soc., 116(1969), 915.

(130) Ж.В.Грановская и И.А.Васильева : Жур. Физ. Хим., 59 (1985) , 329.

(131) Y.Wanibe, Y.Yamauchi, K.Kawai und H. Sakao : Arch. Eisenhüttw., 44 (1973) , 711.

(132) E.Sugimoto and Z.Kozuka : Trans. JIM, 19 (1978), 275.

(133) M. Iwase, S. Miki and T. Mori : J. Chem. Thermodyn., 11 (1979), 101.

(134) M.Kawakami, K.S.Goto and M.Matsuoka:Met. Trans., 11B(1980), 463.

(135) P.Taskinen, A.Taskinen and L.E. Holappa : Scand. J.Metall., 11 (1982), 17.

(136) T.Oishi, T.Goto, Y.Kayahara, K. Ono and J.Moriyama : Met.Trans., 13B(1982), 423.

(137) T.Oishi, K.Kamuo, K.Ono and J.Moriyama: Met.Trans., 14B(1983) , 101.
(138) T.Arato, M.Tokuda and M.Ohtani : Trans. JIM, 25 (1984), 649.

(139) M. Iwase, N. Yamada, E. Ichise and $H$. Akizuki:Arch. Eisenhütttenw., 55 (1984), 415.

(140) M.Iwase, N.Yamada, H.Akizuki and E. Ichise : Arch Eisenhüttenw., 55(1984), 471.

(141) M.Iwase, E.Ichise, N. Yamada and K. Nishida: ISS Trans., 4 (1984), 47.

(142) M.Iwase, N. Yamada, K.Nishida and E.Ichise., ISS Trans., 4 (1984), 69.

(143) M.Iwase, N.Yamada, E.Ichise and H.Akizuki : ISS Trans., 5(1984), 53.

(144) D.A.Neudorf and J.F.Elliott: Met. Trans, 11B(1980), 607.

(145) 山口 周, 今井淳夫, 後藤和弘：日本金属学会 誌, 47 (1983), 736 .

(146) H.Itoh and T.Yokokawa: Trans. JIM , 25 (1984), 879 .

(147) 山口 周, 後藤和弘: 日本金属学会誌, 48(1984), 43.

(148) H.Itoh, A. Sasahira, T. Maekawa and T. Yokokawa: J.Chem. Soc. Faraday Trans., 80 (1984), 473.

(149) 大場秋彦, 後藤和弘：日本金属学会誌, 49 (1985), 517.

(150) R.Y.Lin and J.F.Elliott : Met. Trans., 14A (1983), 1713.

(151) S.K.Mittal and J.F.Elliott : J.Electrochem. Soc., 131 (1984), 1194

（152）たとえば，大塚伸也：溶融塩, 26(1983)，129；P. Taskinen: Scand J. Metall., 13(1984), 75 など.

(153) たと光ば, N.Fukatsu, N.Shidawara and Z. Kozuka : J.Electrochem. Soc., 132 (1985) , 2258; R.V.Kumar, D.A.R.Kay : Met. Trans., 16B (1985)，287など.

(154) たとえば, G.Róg and A.K.-Róg : Electrochimica Acta, 30 (1985)，335など.

(155) 大石敏雄, 小野勝敏: 日本金属学会会報, 25 (1986), 291.
<新 刊案 内 >

非常に有意義である本が，市販されていないために でく一部の人には知られているあのの, なかなか話題 になりにくいてとがある。乙てで紹介する "Platinum Metals Review” あその一つである.

この雑誌は, 希土類, 白金族元素等の高純度金属, 化合物を製造販売している, 英国 Johnson Matthey 社が 1957 年より毎年 1，4，7，10月の 4 回発行してい るむので，白金族元素の金属と化学等に関する最先端 技術の概要紹介を毎号掲載している．乙の雑誌の面白 いところは，タイトルにあるように対象が白金族金属 であれば分野を限定せず，例えば白金族金属や化合物 の物理, 化学という基礎的な面から, 触媒, 電子材料, 磁性材料，医用材料としての性質，製造法等応用面に 関しても，写真入りでわかりやすく紹介していること である. また，白金族金属の発展に貢献した研究者の 伝記屯随時掲載し，白金族金属の歴史に関しても大い なる知見を与えてくれる。

さらに, 雑誌の後半には, 心憎い編集とも言うべき か，毎号かなりのページをさいて，白金族金属とそれ

\section{Review(日本語版・B 5 判)}

Johnson Matthey 社 編 田中貴金属工業株式会社 訳 らの合金に関する最近の文献の抄録や，白金族金属に 関する新しい特許を紹介しており，非常に役に立つよ うにできている。

最近はレアメタルブームで, チタン, ニオブ等の遷 移金属や，希土類金属，半導体等が脚光を浴びている が，白金族金属もまた，多くの可能性を秘め，より多 くの人々に研究されるべきレアメタルであり，乙の分 野への入門あるいは研究動向の把握に Platinum Metals Review は必要不可欠であろう.

幸いなととに，Johnson Matthey 社と提携してい る田中貴金属工業株式会社から, Platinum Metals Review の日本語版が出版され, 無料配布(ただし, 学生は除く)されるようになったので, 白金族金属に 興味のある向きには，是非お鹰めしたい，(M.N.)

〔申込先 : T103 東京都中央区日本橋茅場町 2-6-6 田中貴金属工業(株)技術企画室

(電話 03-668-0111(代)) ) （英語版も希望者に配布する） 